\title{
Author Correction: FRQ-CK1 interaction determines the period of circadian rhythms in Neurospora
}

Xiao Liu, Ahai Chen, Angélica Caicedo-Casso, Guofei Cui, Mingjian Du, Qun He, Sookkyung Lim, Hang J. Kim, Christian I. Hong \& Yi Liu

Correction to: Nature Communications https://doi.org/10.1038/s41467-019-12239-w, published online 25 September 2019.

The original version of this Article omitted the following from the last sentence of the Acknowledgements:

A.C.-C. was supported by Universidad del Valle via the research project CI 71033.

This has now been corrected in both the PDF and HTML versions of the Article

Published online: 14 January 2020

\begin{abstract}
(c) (i) Open Access This article is licensed under a Creative Commons Attribution 4.0 International License, which permits use, sharing, adaptation, distribution and reproduction in any medium or format, as long as you give appropriate credit to the original author(s) and the source, provide a link to the Creative Commons license, and indicate if changes were made. The images or other third party material in this article are included in the article's Creative Commons license, unless indicated otherwise in a credit line to the material. If material is not included in the article's Creative Commons license and your intended use is not permitted by statutory regulation or exceeds the permitted use, you will need to obtain permission directly from the copyright holder. To view a copy of this license, visit http://creativecommons.org/licenses/by/4.0/.
\end{abstract}

(C) The Author(s) 2020 